\title{
Untwisting the Tangled Web: Charles Wesley and Elizabeth Story
}

\author{
RANDY L. MADDOX AND \\ TIMOTHY UNDERHILL
}

\begin{abstract}
The recent publication of a more complete edition of Charles Wesley's manuscript journal provides greater awareness of the personal trials he faced, including an accusation of sexual improprieties in late 1744 . This article summarizes that specific case, identifies the woman involved, introduces a previously unpublished document clearing Charles Wesley of these charges, and reflects on possible motivations for soliciting this document five years after the event.

Keywords: Thomas Broughton, Sarah Gwynne Jr, Elizabeth Story, Charles Wesley, Thomas Williams

One of Charles Wesley's greatest personal trials came to a head in 1744. But the intensity of this trial, as well as many of the details of those involved, have gone unrecognized by most readers. Part of the reason is prior editorial practice. Thomas Jackson omitted from his published version of Charles Wesley's journal most of the pertinent entries and provided no annotations to highlight the matter. ${ }^{1}$ Fortunately, these shortcomings were corrected in the recent new edition of Charles Wesley's manuscript journal. ${ }^{2}$ This article will draw together the relevant information in this new edition, as well as introduce an important clarifying document that was previously unpublished.
\end{abstract}

1. Some entries were omitted because they were in shorthand (in which Jackson was not proficient). Others were omitted because of their potential to cast Charles Wesley (CW) in a negative light.

2. Compare the references to CW's journal that follow in The Journal of the Rev. Charles Wesley, M.A., ed. Thomas Jackson (London: John Mason, 1849) and The Manuscript Journal of the Rev. Charles Wesley, M.A., ed. S T Kimbrough Jr and Kenneth G. C. Newport, 2 vols (Nashville, TN: Kingswood Books, 2007, 2008). The manuscript original is held at the Methodist Archives and Research Centre (MARC) at the John Rylands Library, DDCW 10/2.

WESLEY AND METHODIST STUDIES, Vol. 8, No. 2, 2016

Copyright (c 2016 The Pennsylvania State University, University Park, PA 
While the incident under consideration boiled over in 1744 in London, its roots ran back at least three years. Thomas Williams (c.1720-87), a native of Llanishen, Glamorgan, Wales, matriculated at Jesus College, Oxford, in 1739. He did not complete a degree. In July 1741, having returned home to Llanishen, Williams heard Charles Wesley preach and was converted. Williams began travelling with Charles Wesley and also assisting John Wesley. In 1743 he ran afoul of Church of England clergy in Darlaston and Walsall, and was criticized by John Wesley for his 'inexcusable folly' at Wednesbury. ${ }^{3}$ These events fostered some estrangement from the Wesley brothers, leading Williams to seek ordination in the Church of England in early 1744. Rather than support Williams in this attempt (which was not successful), Charles Wesley chastised him for being 'too hasty', in part because Williams lacked a university degree.

Williams's response, as Charles Wesley reported, was to rage and rail against the Wesley brothers 'as Papists, tyrants, enemies of the Church, etc.' and to vow revenge. His efforts found effect particularly 'among the young women, who are ready to tear me to pieces for "my cruelty to poor dear Mr. Williams, and hindering him from getting orders"'.5 Apparently with the goal of drawing a number of the Foundery society away from the Wesley brothers to establish his own church, Williams specifically began to circulate rumours of Charles Wesley keeping mistresses. ${ }^{6}$

As things heated up another former colleague of the Wesley brothers entered the picture. Thomas Broughton (1712-77) was drawn into the 'Oxford Methodists' in 1733 during his studies at University College and as a fellow of Exeter College. In early 1738 he renewed connection with John and Charles Wesley, following their return from Georgia, while serving as curate at the Tower of London. But by the end of that year the three had grown apart, as Broughton rejected the Wesley brothers' new emphases on instantaneous conversion and assurance of faith. This alienation was reinforced in March 1739 when a prostitute (one ' $\mathrm{H}$. T.), whom Charles Wesley and members of the London society had sought to redeem, accused Broughton of sexual impropriety. Charles Wesley was torn, believing Broughton innocent but not willing to declare his convert a liar, even when the case came to the attention of Edmund Gibson, Bishop of London. ${ }^{7}$ Stung by what he considered a lack of support, Broughton took advantage of the

3. See the entry for 15 April 1743 in Journal and Diaries II (1738-1743) [vol. XIX of The Works of John Wesley], ed. W. Reginald Ward and Richard P. Heitzenrater (Nashville: Abingdon Press, 1990), 322. (This is a correction to the identification of 'Williams' as Robert Williams [322 n. 85].)

4. Manuscript Journal, II:403 (2 May 1744).

5. Ibid. II:404 (12-13 May 1744).

6. See ibid. II:405 (2 June 1744) and II:423 (25 September 1744).

7. See ibid. I:164-9 (8-24 March 1739). 
opportunity four years later to turn the tables. He collected an affidavit from at least one woman who had left the London society over what she considered the mistreatment of Thomas Williams, and delivered it to Bishop Gibson. ${ }^{8}$

One of the items missing from Jackson's edition of Charles Wesley's journal is his copy of a letter to the bishop refuting this charge. ${ }^{9}$ It warrants reproducing in full, and is given as it appears in the new edition.

My Lord

I was informed some time ago that your Lordship had received some allegations against me of one E. J. charging me with committing or offering to commit lewdness with her.

Farther, I have lately heard that your Lordship was pleased to say, 'If I solemnly declared my innocence you should be satisfied. I therefore take this liberty and do hereby solemnly declare that I never did commit lewdness with that person, nor solicit her to it, and that I am innocent in deed, word, and thought touching this thing.

As there are, I hear, other such slanders cast upon me and no less than all manner of evil said against me, I must beg leave farther to declare my innocence as to all other women likewise. It is now near 20 years since I began working out my salvation. In all which time God, in whose presence I speak, has kept me from either committing the act of wickedness (fornication, or adultery) or even soliciting any person whatsoever thereto. I deny the action. I deny that I have ever spoken any word prompting any person thereto.

8. Broughton's role was described in a letter of Howel Harris to George Whitefield (11 January 1745), in Gomer Morgan Roberts, ed., Selected Trevecka Letters (1742-1747) (Caernarvon: Calvinistic Methodist Bookroom, 1956), 162. Harris spoke of two women giving affidavits.

9. The actual letter sent to Bishop Gibson is not known to have survived. We have copies CW made for his records in two forms: one is in longhand in his MS Journal (MARC, DDCW 10/2; Manuscript Journal, II:435); the other is in shorthand in a notebook of copies of letters (MARC, MA 1977/567/2, p. 31). The former is the source for the transcription in The Letters of Charles Wesley, ed. Kenneth G. C. Newport and Gareth Lloyd (Oxford: Oxford University Press, 2013), I:116. There are several minor differences between the longhand and shorthand versions, including the date of the letter (the shorthand copy dates it 8 February). The shorthand copy may be closer to the sent letter, with the longhand copy (like the MS Journal as a whole) being a later polished presentation. Apparently unaware of the longhand copy, John Telford came upon the shorthand copy and published an expansion of it in his edition of The Letters of the Rev. John Wesley, A.M., 8 vols (London: Epworth Press, 1931), II:28. There are three errors in Telford's expansion: the sixth line of the first paragraph should read 'would' instead of 'should'; the second line of the second paragraph should end 'beg leave further' instead of 'beg leave first'; and the second line of the last paragraph should end 'take the blessed sacrament in' instead of 'take the oaths in'. With these alterations Telford's copy provides a reliable expansion to compare CW's shorthand copy to the longhand copy given here. We give the longhand version because it includes CW's identification of the woman involved. 
I deny that I have ever harboured any such design in my heart. If your Lordship requires any further purgation, I am ready to declare the same viva voce and to take the blessed Sacrament in proof of this, my declaration.

I am, my Lord, your Lordships' dutiful son and servant, C W

The Foundery [London]

February $7,1745^{10}$

This letter raises several questions, including the identity of ' $\mathrm{E}$. J.' and whether there is any collaboration for Charles Wesley's plea of innocence. While combing through a range of John and Charles Wesley manuscript items over the past two years Randy Maddox happened upon (almost simultaneously) two independent copies of a relevant document. One is in the Methodist Archives and Research Centre at the John Rylands Library of the University of Manchester. ${ }^{11}$ This item comprises simply the outside covers of a notebook from which all the pages have been torn. But inside the front cover Charles Wesley had transcribed a document in shorthand. Finding no previous expansion of this shorthand document, Maddox was delighted when Timothy Underhill (an expert in Byrom's shorthand, which Wesley used) agreed to work on it. While we were puzzling over a few final items in the shorthand, Maddox happened upon a longhand copy of the same document at the Moravian Archives in London. ${ }^{12}$ We include below a transcription that is based on the longhand document but notes variants in the shorthand version. ${ }^{13}$

\section{A Copy of Elizabeth Story's Declaration}

December $9 / 20,1748^{14}$

Elizabeth Story hereby declareth that she has had no rest or peace in her soul since she reported certain things and afterward made affidavit thereof concerning Mr. Charles Wesley, ${ }^{15}$ which

10. Manuscript Journal, II:435.

11. MARC, MA 1977/568; published by courtesy of The University of Manchester and the Trustees for Methodist Church Purposes.

12. In a folder of William Holland materials: AB91/WmHollandFolder/6.

13. The transcription updates archaic spellings, expands contractions, and adapts to modern principles of capitalization and punctuation.

14. The first of the two dates given in the heading (9 December) was that of Story's original affidavit; the second (20 December) was apparently that of Sarah Verine's final addition. The copy itself was made on 31 January 1749.

15. In the shorthand copy CW is not named; the manuscript leaves a gap instead. This also occurs with Story's subsequent reference to him. 
report and affidavit were entirely false. That she has felt continual condemnation in her heart and has never prospered in soul or body since that time. That Mr. [Thomas] Broughton, when she related those false matters, did caution her not to speak anything but what was the truth. That the cancer which she had in her breast she believes might be occasioned by her striking her breast against a chair. ${ }^{16}$ That she freely and gladly maketh this declaration, hoping the Lord will forgive her this great sin, and desires ${ }^{17} \mathrm{Mr}$. Wesley's pardon for speaking and declaring such false things concerning him, being prompted thereto through ${ }^{18}$ the instigation of the devil.

This is the truth as witness my hand this ninth day of December 1748

Elizabeth Story

\author{
Witnessed by \\ William Holland \\ Eliza[beth] Cart \\ and \\ Sarah Verine
}

[[To Mrs Hall ${ }^{19}$ at Mrs $\left[\right.$ Begrs $\left.^{20}\right]$ in Saint Thomas church yard Sarum]]. ${ }^{21}$

Elizabeth Story told Mrs. Verine and her mother that it was through the persuasion of Mr. [Thomas] Williams and others that she had declared such false things concerning Mr. Charles Wesley, for that she had never seen an unhandsome action or heard a bad word from him in her life, was it the last word she was to speak. And when they asked her afterwards how she came to tell such lies of Mr. Charles Wesley, she replied that she had told a thousand lies of him in one week.

The mark of Sarah Verine $\mathrm{X}^{22}$

16. She had apparently alleged earlier that the cancer was judgement for her impropriety with CW.

17. Shorthand copy adds 'also' after 'desires'.

18. Shorthand copy reads 'by' instead of 'through'.

19. That is, Martha (Wesley) Hall, CW's sister.

2o. This surname has so far eluded confident transcription and identification; there is probably a possessive apostrophe preceding the 's'.

21. This address information is found only in the shorthand copy.

22. Shorthand copy omits 'The mark of' but shows the 'X', both here and below. 
Elizabeth Story declared also to Mrs. Cart and William Holland that it was through the persuasion of Mr. [Thomas] Williams and others that she spoke, and afterwards made affidavit of such false things concerning Mr. Charles Wesley, and what greatly concerned her was that she had been the means of turning many souls out of the way thereby. And although ${ }^{23}$ others did persuade her to act so, yet they could not have made her done it unless she herself had been willing. That she did not hereby excuse herself, for she was bad enough and that God knew.

William Holland Eliza[beth] Cart ${ }^{24}$

A few days after that she ${ }^{25}$ had made the declaration which was signed by William Holland, Elizabeth Cart, and Sarah Verine, she desired, with tears in her eyes, the said Sarah Verine, ${ }^{26}$ for God's sake, that when she went next time ${ }^{27}$ to Mr. Charles Wesley she would tell him that she had not felt such peace for five years past. Although she could not then say she felt the pardoning love of God as she had formerly, and was afraid as her sin was so great that she never should so experience it again, and in great anguish of soul cried out, 'O God, how have I torn myself from thy people that would have been friends to me both in body and soul.'

The mark of Sarah Verine X [December 20, $1748^{28}$ ]

A Copy / January 31, 1748/9 ${ }^{29}$

The first point that this document makes clear is that Charles Wesley's manuscript capital 'S' was misread as a 'J' in the new published edition of his journal (the letters are similar in shape). The identification of Elizabeth Story as the accuser is consistent with the lists of single women in the Methodist bands at the Foundery in London-for she appears on a list for April 1742, but not in

23. Shorthand copy reads 'though'.

24. Shorthand copy adds a third signature: 'Sarah Verine X'.

25. Shorthand copy replaces 'she' with 'Elizabeth Story'.

26. Shorthand copy reverses the order of the two preceding clauses.

27. Shorthand copy reads 'went the next'.

28. Taken from the heading.

29. This comment is found only on the longhand copy in the Moravian Archives, indicating that it was a manuscript copy of the original affidavit. CW's shorthand copy may well have been made from the same original. That original has not been located to date. 
lists for 1744-45 after Thomas Williams had begun spreading dissent. ${ }^{30}$ And there seems little reason to doubt the veracity of Story's recantation, since Williams recanted in December $1744 .^{31}$

So this document provides answers to some important questions. But it also raises a new one-related to timing. It was not produced as support for Charles Wesley's defence at the time of his appearance before Bishop Gibson, and Thomas Williams had long since recanted the original accusation. What led to seeking this formal affidavit nearly five years after the event? It is possible that Elizabeth Story's conscience simply got the better of her over time. But two other possible motives should be considered.

In the first place, Charles Wesley was in London from mid-December 1748 through early January 1749 specifically to consult with trusted friends about whether he should marry Sarah Gwynne Jr. It is quite possible that they advised obtaining a formal documentation of his innocence of this old charge, in case it came to the attention of the Gwynne family.

The second possibility is suggested by the only detail that appears in Charles Wesley's shorthand copy but not the longhand copy-a record that he mailed the initial declaration by Elizabeth Story to his sister Martha (Wesley) Hall in Salisbury. This is significant because about a year earlier Martha had suffered through the public exposure of her husband's infidelity and desertion. It is possible that Martha objected to Charles proposing marriage if he was also already 'married' in God's eyes by the earlier alleged incident. Alternatively, Martha was considering leaving Salisbury (where she had been living when Westley Hall abandoned her) and accepting the hospitality of her brothers in London. A last obstacle to this move may have been fear that she would be stepping into a new controversy over fidelity. Whatever her concern that led Charles to send her a copy of the recantation, by 17 April 1749 Martha had moved to London, from where she wrote Charles a warm letter of congratulations on his marriage to Sarah Gwynne Jr. ${ }^{32}$

While Martha's congratulatory letter has long been known, only now can we fully appreciate how tangled matters had become, and the apparent efforts to clarify the 'Elizabeth Story story' prior to Charles and Sarah's wedding. But any joy over the averted potential disruption of Charles's union with Sarah must be

30. The lists are also in MARC, part of the Colman Collection; see MA 1977/503, Box 1, Book 2, (unnumbered) p. 7. Nothing certain is known of Elizabeth Story beyond the presence of her name on the 1742 band list and documents considered in this article.

31. See John Wesley's entry for 2 December 1744 in Journal and Diaries III (1743-1754) [vol. XX of The Works of John Wesley], ed. W. Reginald Ward and Richard P. Heitzenrater (Nashville: Abingdon Press, 1991), 44.

32. MARC, DDWes 1/34; transcription published in George J. Stevenson, Memorials of the Wesley Family (London: S. W. Partridge, 1876), 374. 
balanced by recognition that Charles suffered significant disruption of at least two close friendships at the time the accusations of Williams and Story came to light. The one that he lamented most poetically was a relationship that had grown over the prior four years with his 'bosom friend' Sarah Perrin. ${ }^{33}$ Their near biweekly letters dwindled in early 1745 and entered a hiatus of at least four years. The other friendship that was strained for some time by the accusations (and Charles Wesley's perception that his 'friend' did not immediately accept his plea of innocence) was with Selina, Countess of Huntingdon. ${ }^{34}$ In this case it was nearly six years before the friendship (and correspondence) resumed.

The one relationship never significantly restored was between Charles Wesley and Thomas Williams. When Williams recanted the charges he had made in December 1744, John Wesley began to employ him again as a travelling preacher in a probationary status. In 1747 John even sent Williams to Ireland to open the Wesleyan Methodist work there. ${ }^{35}$ But Charles Wesley was less forgiving. When Williams sought contact with him in 1746, Charles delegated the matter to an assistant, insisting that Williams's 'promises of repentance had little weight with me.3. ${ }^{36}$ And Charles surely felt vindicated when his brother John ended up expelling Williams again in 1755 for an unknown offence. ${ }^{37}$ For Charles Wesley, Williams became the exemplar of a scandalous minister, as reflected in his comment about another problematic Methodist preacher in 1756 that 'Thomas Williams himself was nothing to him..3

RANDY L. MADDOX is the William Kellon Quick Professor of Wesleyan and Methodist Studies at the Divinity School, Duke University. He is author of Responsible Grace: John Wesley's Practical Theology, a contributor to Wesley and

33. See 'An Address to a Friend' in MS Shorthand Letters (MARC, MA 1977/567); transcribed in the online collection of Charles Wesley's Manuscript Verse, Center for Studies in the Wesleyan Tradition, Duke Divinity School <http://divinity.duke.edu/initiativescenters/cswt/wesley-texts/manuscript-verse> accessed 16 January 2016.

34. See particularly the shorthand entry for 3 January 1745 in CW's journal (an entry omitted by Jackson): MARC DDCW 10/2, p. 243 (CW's pagination). Manuscript Journal, II:432-3 transcribes this, but overlooks CW's interlineation of the word 'Sarah' above 'Robinson'.

35. See Charles H. Crookshank, History of Methodism in Ireland (Belfast: Allen, 1885), $\mathrm{I}: 14-15$.

36. Manuscript Journal, II:475 (11 September 1746).

37. Owen E. Evans, 'Williams, Thomas c. 1720-1787', Dictionary of Methodism in Britain and Ireland, ed. John A. Vickers <http://www.wesleyhistoricalsociety.org.uk/dmbi> accessed 20 January 2016. Subsequent to this expulsion Williams was ordained into the Anglican ministry, through the advocacy of Lady Huntingdon, serving in High Wycombe, Buckinghamshire.

38. Manuscript Journal, II:638 (21 October 1756). 
the Quadrilateral, and editor of Aldersgate Reconsidered, Rethinking Wesley's Theology for Contemporary Methodism, The Cambridge Companion to John Wesley, and Volume 12 of the Bicentennial Edition of The Works of John Wesley.

TIMOThy UNDERHILL is Assessment Manager for English at Cambridge University's international assessment department. His doctoral thesis was on John Byrom and he has published a number of articles on Byrom's life, writing, and shorthand. He has deciphered shorthand materials to inform texts of Charles Wesley's verse published online by Duke Divinity School's Center for Studies in the Wesleyan Tradition, and also for the Oxford University Press edition of Charles Wesley's Letters (ed. Kenneth G. C. Newport and Gareth Lloyd). He is working on an edition and fuller biographical study of Byrom and his circle. 